\title{
TJBF EMPIRICAL DETERMINANTS OF US EQUITY FLOWS TO DEVELOPED COUNTRIES: DOES VALUATION MATTER?
}

\author{
Joseph J. French \\ University of Northern Colorado, \\ United States of America
}

\begin{abstract}
This paper explores a new panel data set on US gross cross-border equity flows to 20 industrialized nations combined with measures of market valuation for the period of 1977-2005. Empirical evidence of imperfect integration across world equity markets indicates that valuation matters. Consistent with relative value trading as a determinant of equity flow patterns, we find that quity flows decrease sharply with host-country market valuations. This paper also finds that equity flows increase sharply with US equity market valuations. The findings of this research suggest that American investors are informed about both domestic markets and foreign markets. Peripheral findings of this research confirm the findings of other researches, but this research is based on a longer sample period. Consistent with existing literature, there is a negative influence of interest rates spreads, and information asymmetries on cross-border trades in equities.
\end{abstract}

Keywords: Equity flows, Cross-border portfolio investment, International markets

JEL classification: F21, G15, G14, 016, G11

\section{Introduction and Motivation}

The past two and a half decades have been characterized by a dramatic increase in international capital mobility. In 1975, gross cross-border transactions in bond and equity flows for the US residents were equivalent to only 4 percent of GDP. This share increased to 100 percent in the early 1990s and has continued to increase to 245 percent at the turn of the current century. Furthermore, a growing percentage of these portfolio flows consists of equity (Hau and Rey, 2006). However, empirically, there are few established results on the determinants of equity flows between nations (Portes and Rey, 2005). 
Empirical work has been stymied by data problems, imperfect mobility of capital, and behavior of international investors which is contrary to established theory. Empirical agreement has also been difficult to reach because different researchers focus on different time-periods and different sets of countries. For example, Calvo, Leiderman and Reinhart (1994) focus on the role of external (push) and internal (pull) factors as potential determinants of foreign investment using a cross section of developing nations. They found that low interest rates in the US played an important role in accounting for the revival of equity flows to these nations in the 1990's. Using data on bilateral portfolio equity flows from a set of 14 industrialized countries during 1989-1996, Portes and Rey (2005) find evidence that imperfection in the international credit markets and variables that proxy information asymmetries have the greatest influence on cross-border equity flows.

This paper investigates the factors motivating cross-border equity flows to developed countries from large US investors. The traditional literature on the empirical determinants of equity flows have not paid particular attention to the overall role that equity markets play in shaping long-term portfolio investment decisions among a cross-section of developed nations. Equity market variables have been considered in the portfolio approach to modeling capital flows, but this literature is concerned with addressing the issues of the lead and lag relationships between equity flows and prices. In the traditional literature on the determinants of equity flows for a broad cross-section of countries, the role of equity market valuation has only been considered peripherally. The effects of diversification on cross-border equity flows have been dealt with extensively in literature (Stulz, 1999, Griffen, Nardari, and Stulz, 2004, Rey and Hau, 2006). In the portfolio approach to understanding equity flows, authors are primarily concerned about modeling the linkages between equity flows and equity markets. The focus of this research in on the long-term empirical determinants of equity flows using traditional capital flows equations and a cross section of countries. Most theoretical models and empirical studies have correctly assumed that cross-border equity flows are the outcome of home investors attempting to optimally diversify and the resulting equity flows reflect the behavior of investors adjusting portfolio weights. The influence of equity market valuation on cross-border equity flows to developed nations has not been considered in the traditional capital flow literature. However, in reality relative value trading is common, The US Offshore Funds Directory (1999) lists several dozen hedge funds that use 'pair trading' as one of their principle equity investment strategies. This finding indicates that relative market valuations are important, to one subgroup of American investors.

There is theoretical support that longer term US investors may have an advantage over hedge funds in relative value trading. Shleifer (2000) and Brunner and Nagel (2004) suggest that longer-term investors have an advantage over short-term hedge funds. For example, suppose a hedge fund manager sells 
an overvalued stock short. If overpricing increases before it reverses, she may be obligated to close the position due to the margin requirements or the agency problem, suggested by Brunnermeir and Nagel (2004), which shortens the horizon period. The fact that hedge funds are engaged in relative value trading implies that there is incentive for longer-term US investors to also be engaged in such strategies.

Further evidence that valuation may be an important factor in understanding why equity flows between nations is evidenced by empirical findings of 'Siamese twin' stocks, which shows that the same stock can trade at different prices in different markets. Froot and Dabora (1999) find that Royal Dutch and Shell transport have often not been priced in line with their relative claims on cash flows. In the early 1990's, the two companies merged with an agreement that entitles Royal Dutch and Shell to split the two entities' combined cash flows on a 60:40 basis. This agreement was in place until the two firms officially merged in 2005. Theoretically, Royal Dutch should have been priced at 60:40=1.5 times the value of Shell. However, the stock price was observed to vary between 36:40 $=0.9$ and 66:40=1.65 times the value of Shell. Since Royal Dutch and Shell trade in possibly the two best functioning financial markets (USA and UK) and other 'twin' shares display similar behavior (Froot and Dabora 1999), it is likely that relative mispricing of corporate equities across international capital markets is common. The Royal Dutch shell experiment ended with the final combination of the two entities.

There is a dearth of studies of the influence of equity market valuation on gross equity flows. The majority of the literature in this area (see Stulz, 1999, Rey and Hau, 2006, and Bohn and Tesar, 1996) has assumed cross-border equity flows occur in an integrated and efficient international capital market and are result of portfolio allocation decisions. This paper steps back from this assumption and introduces the possibility that equity flows may be motivated by equity market valuation in an international capital market that is not completely integrated or efficient. As the Royal Dutch Shell case, coupled with the relative value trading patterns of large hedge funds illustrates, the world market is likely not completely integrated. The primary objective of this research is to consider the implications of stock market valuation as a determinant of cross-border equity flows. Specifically, this paper considers the role of equity market valuation on cross-border equity flows between the US and 20 industrial countries. The questions this research addresses are: How does source country valuation influence long term patterns of equity flows and how does host country valuations influence long term patterns of equity flows. In addition, this paper contributes to the literature in nature of the data. This paper presents results that span almost three decades, for 21 nations, and controls for fundamental determinants of equity flows found in previous literature. The relatively long time horizon of this data allows for testing of other fundamental determinants of equity flows without some of the time horizon problems in other literature.

To test whether relative valuations help to explain equity flows between countries, methodology that helps to determine the presence of a valuation 
effect. This paper analyzes how equity flows depend on host and source country stock market valuations. The key econometric issue is to determine whether the correlation between equity flows and stock market valuation is due to relative value trading or, alternatively from traditional determinants of equity flows. This paper begins with a general empirical methodology is applied to the main sample, which merges the Treasury International Capital (TIC) data on equity flows and the extended international stock market valuation and returns data assembled by Kenneth French. The merged sample spans 1977-2005, and includes observations on 21 countries.

The analysis involves panel regressions of equity flows on source and host country stock market valuations measures. It is found that equity flows are very strongly negatively related to the average market-to-book, price-to-earning, priceto-cash earnings, and dividend yield ratios of publicly traded firms in the host country. Furthermore, host country valuations have as strong or stronger effect than essentially any other determinant of equity flows considered. At the same time, equity flows are strongly positively influenced by US market valuations. This suggests that high US valuation encourages long-term reallocation abroad. This research also documents consistent with other literature on the empirical determinants of equity flows: 1) That proxies for information asymmetries are negatively related to equity flows, 2) That as interest rate spreads increase (i.e. foreign interest rate above US rates) equity flows decrease, 3) That equity flows are negatively related to tax rates of host countries.

The remainder of this paper is structured as follows: Section 2 outlines the methodology, Section 3 discusses and describes my data, Section 4 presents the results, and Section 5 concludes this paper.

\section{Methodology}

Panel data methodology is used to test the effects of mispricing as an empirical determinant of equity flows. This methodology is common in traditional capital flow literature. Panel data methodology is employed and is appropriate for several reasons. First, panel data techniques solves or at least reduces some of the problems by associated with few degrees of freedom by increasing the data points. Second, it is the appropriate estimation technique to alleviate the effects of omitted time-invariant variables that are correlated with explanatory variables. Third, panel structure recognizes that each country can have its own country specific effects, which can be correlated or uncorrelated with some or all of the explanatory variables. Fourth, panel data estimation method is among the most efficient techniques to analyze the impact of a common set of factors across diverse country groupings (Greene, 2003 and Calvo, Leiderman and Reinhart, 1994). Country level stock market valuation ratios and returns to proxy valuation. Because of the problem with model misspecification, particularly the difficulty is to individually identify the effect of market valuation from the effects of other factors on equity flows, because of these considerations; several competing models are estimated (Baker, Foley and Wrugler, 2007). Assume that 
equity flows from the US (indexed with i) to host country (index with j, give time t) is a function of the following:

$$
f_{i j t}=\left(\delta_{i t}, \delta_{j t}, \phi_{i t}, \phi_{j t}\right)
$$

where $\delta_{i t}$ is the degree of overvaluation in country $\mathrm{i}$ at time $\mathrm{t}$ and $\phi_{i t}, \phi_{j t}$ represent vectors of control variables, for example past returns (Bohn and Tesar, 1996), interest rates spreads (Chulan et al, 1998), country dummy variables, and information variables (Portes and Rey, 2005). This research hypothesizes that that controlling for the other determinants of equity flows that flows should decrease with the degree of valuation in host country or $\delta_{i t}<0$, and increase with the degree of valuation in the source country or $\delta_{j t}>0$.

To empirically test the above hypotheses, this research develops the relationship between valuation and gross equity flows assuming that expected returns are a function of commonly used valuation ratios:

$$
E\left(r_{i t}\right)=f\left(M / B_{i}, P / E_{t}, D / P_{t}\right)
$$

where $M_{i t} / B$ is the book to market ratio for country i at time t, $P_{i t} / E$ is the earning to price ratio for country $i$ at time t and $D / P_{i t}$ is the dividend to price ratio for country $i$ at time $t$. The determinants of differential stock returns are stable over time, and the forecasting power of Fama and French types of models are surprisingly high. (Haugen, 1996). The variables used to valuation are common in literature, it has been found that market-to-book value serves as a rough proxy of underlying fundamentals; a low market-to-book suggests that the country's stock market is undervalued (Kothari and Shanken, 1997). Fama and French (1998) find that market-to-book is inversely related to future equity returns for international stocks and Basu (1983) and Fama and French (1992) find similar for US stocks. Additionally, Kothari and Shanken (1997) find that aggregate market-to-book is negatively related to subsequent returns. They also find that in some time periods dividend-to-price outperforms book to market. Additionally, the common use of price to earnings ratios by practitioners (Graham and Harvey, 2001) and the findings of Chuhan, Claessens and Mamingi's (1998) argues for the consideration of the earnings to price ratio. According to Kathari and Shanken (1997) one view of the predictive power of financial ratios reflect the degree to which the market is overvalued (high MB or PE) or undervalued (low MB or $\mathrm{PE}$ ) at a given point in history. In the case of overvaluation, for example, future returns (and hence true expected returns) will be low insofar as the overvaluation is likely to be corrected over time. They find that overwhelming evidence that returns are forecasted by BM and dividend yields, casting doubt on the efficient market hypothesis.

Several different models are considered in order to get the most consistent and efficient results possible. The starting point will be a pooled ordinary least squares regression. Consider the following general panel regression framework (modified from Green, 2003): 


$$
f_{i j t}=z_{i} \alpha+x_{i t} \beta+\varepsilon_{i t}
$$

where $f_{i j t}$ is a scalar dependent variables, observed for country $\mathrm{i}$ at time $\mathrm{t}$, $x_{i t}$ is a $\mathrm{K}$ dimensional vector of data that varies overtime, and $z_{i}$ is a vector of data that varies across countries, but is constant over time. One could consider this a country effect. The first model considered is pooled regression. Pooled regression considers $z_{i}$ to be observable for all countries, and common estimates of parameters should be found through ordinary least squares on pooled data. The problem is that if $z_{i}$ is partially unobservable and if the unobservable portion is correlated with $x_{i t}$, then the parameter estimates will be biased and inconsistent. In order to correct this potential problem fixed effects models are also considered. Fixed effects model assumes that $z_{i} \alpha=\alpha_{i}$, or estimates country specific intercepts that do not vary over time to capture unobserved heterogeneity (Greene, 2003). In order to determine whether fixed effects are appropriate I will estimate the following LM test for group effects. Under the null hypothesis $\alpha=\alpha_{i}$ for all countries. Under the alternative hypothesis intercepts vary from country to country. If one fails to reject the null hypothesis then the appropriate efficient estimator is pooled OLS. The F statistic for this test is calculated as:

$$
F(N-1, N T-N-K)=\frac{\left(R_{F E}^{2}-R_{p o o l e d}^{2}\right) / N-1}{1-R_{F E}^{2} / N T-N-K}
$$

If the null hypothesis is rejected, then fixed effects model could be the appropriate method or potentially another class of panel data models may be appropriate. A random effects model assumes that unobserved heterogeneity is uncorrelated with $x_{i t}$ and models $z_{i} \alpha=\alpha+u_{i}$, where $u_{i}$ is an individual specific disturbance that is drawn once and is not allowed to change over time. So random effects allow for differing intercepts across individuals, but the variation is the result of a draw from a random distribution. The appropriate estimation technique crucially depends on the nature of the latent variable. In order to test whether fixed effects or random effects is appropriate Hausman Wald Style test (Hausman and Taylor, 1981) are estimated. Under the null hypothesis $\beta^{R E}-\mathrm{B}^{F E}$ $=0$, this implies that both estimation techniques are consistent. If the test fails to reject the null hypothesis then, while both estimation techniques are consistent random effects model will give more efficient parameter estimates. The Hausman test statistic is calculated in the following manner (Greene, 2003):

$$
H=\left(\beta^{R E}-\beta^{F E}\right)^{\prime}\left[\operatorname{Var}\left(\beta^{F E}\right)-\operatorname{Var}\left(\beta^{R E}\right]^{1}\left(\beta^{R E}-\beta^{F E}\right)\right.
$$

Which is distributed chi-squared with degrees of freedom equal to the number of parameters in the $B_{F E}$ coefficient vector. Rejection of the null hypothesis rejects that the random effects model holds.

The following model is estimated to see whether valuation ratios better explain cross-border flows than lagged returns (i.e. return chasing), by including lagged returns as an additional variable. 


$$
f_{i j t}=\alpha+b_{1}\left(\frac{m}{b_{i t}}\right)+b_{2}\left(\frac{m}{b_{j t}}\right)+b_{3}\left(\log d i s_{i j t}\right)+b_{4}\left(R_{i t-1}\right)+\varepsilon_{i j t}
$$

If it is found that $b_{1}<0$ this does not prove the hypothesis and $b_{2}<0$. As market-to-book, earnings-to-price, or dividend to price may be a good proxy for $\delta$ in the above regressions do not control for other factors, which may influence equity flows. For example, some theories link interest rate differentials, industrial production, tax rates, country of legal origin, and exchange rates with equity flows and these fundamentals may be correlated with the stock market. This will result in the betas above being bias estimators. However, market to book, price to earnings and dividend to price ratios are exchange rate invariant and may be a good proxy for $\delta$. Then the following panel regressions will be run to determine the basic relationship between valuation and equity flows to control for other factors directly.

$$
f_{i j t}=\alpha_{i}+\beta_{l}\left(m_{i t} / b\right)+\beta_{2}\left(m_{j t} / b\right)+\beta_{4} X_{i}+\varepsilon
$$

where $\mathrm{X}$ represents a vector of control variables and $f_{i j t}$ represents inflows as a percentage of initial stock. Model using cash earning to price, price-toearnings, and dividend yield are also estimated. If cross-border equity flows are influenced by equity market valuation then $\beta_{1}<0$ and $\beta_{2}>0$. In addition, the marginal difference in valuation to induce flows will be lower for more developed economies, because the amount of friction is smaller. To control for this a variable to proxy time varying information asymmetry and institutional development is included. Additionally, country level fixed effect should control for these concerns.

\section{Data and Summary Statistics}

Portfolio flows are distinguished from other international capital flows by the degree the flows can be reversed. Some clarification and definitions may be useful. Capital flows are generally broken into three flows: Direct Foreign Investment (FDI), bond flows, and equity flows. FDI flows are distinguished from other international capital flows by the degree to which the investor owns or controls the firms. FDI is typically defined as the direct or indirect ownership or control by a single domestic entity of at least ten percent of the voting securities of an incorporated foreign business firm or the equivalent in an unincorporated enterprise. Bond flows represent flows from the US to foreign bond markets for portfolio reasons. Similarly, equity flows used in this study represent flows from US investors to foreign equity markets for portfolio reasons. The source for the equity flows used in this study is from U.S Department of the Treasury (TIC).

Data from the U.S Department of Treasury is the most comprehensive source of publicly available data for cross-border equity flows (Tesar and Warner, 1994). TIC is the appropriate data set to test the longer term influences of equity market valuation, because the data taken from reports are mandatory and are 
filed by banks, securities dealers, investors, and other entities in the U.S., who deal directly with foreign residents in purchases and sales of long-term securities (equities and debt issues with an original maturity of more than one year) issued by U.S. or foreign-based firms. The data reflect only those transactions between U.S. residents and counterparties located outside the United States. Flows are calculated from a foreign perspective (i.e. non-U.S resident). Hence, inflows to country $i$ would be from the US minus outflows from country $i$ to the US. The data span is 1977 to 2005 and include observations in which 20 countries are the host of equity flows out of the US. The series are reasonably complete, and they have been collected on a consistent basis over time. Equity flows as percentage of initial equity position are measured; this is consistent with Tesar and Werner (1995), Chuhan et al (1998) as:

$$
f_{\text {usajt }}=\frac{\text { flow }_{t}^{\text {usa } \rightarrow j}}{\text { Position }_{t-1}^{u s a \rightarrow j}}
$$

where the US is the source country and $\mathrm{j}$ is the host. Scaling by initial position renders the equity flow measure more comparable across countries. While scaling is not important in regressions where country fixed effects are included, in regressions where legal origin is included, it is preferable not to use country fixed effects, because time constant variables drop out of fixed effect estimations, so this scaling is appropriate. Additionally, since small initial positions can lead to outliers in this measure, the flow variable is winsorized at +100 percent.

Stock market valuation and return are obtained data from Kenneth French's website. This data includes annual observations of the capitalization-weighted market-to-book, dividend to price, cash earning to price, equity to price, and stock market returns in both dollars and local currency for 20 countries for the period of 1975 to 2005 for most countries. The countries included are: Austria, Australia, Belgium, Canada, Finland, France, Germany, Hong Kong, Ireland, Italy, Japan, Malaysia, Netherlands, New Zealand, Norway, Singapore, Spain, Sweden, Switzerland, and the United Kingdom. Kenneth French's data was constructed using MSCI, CRSP and COMPUSTAT data. Fama and French (1998) claim that the construction used does not suffer from survivor bias. The raw data are from Morgan Stanley's Capital International Perspectives (MSCI). The set of firms whose data is used to construct country-level returns and valuation ratios is essentially the set of firms included in Morgan Stanley's stock index for that country. These tend to be large firms, and for a typical country cover roughly 80 percent of the domestic stock market capitalization.

Control variables are gathered from several sources. The real exchange rate is calculated from nominal exchange rates and price indices from the IMF International Financial Statistics (IFS). Exchange rates are indexed with the US dollar exchange rate in 1995 set to one in each country. Real exchange rate is included to capture the increase in productivity over a given period, (Cavlo et al, 1994), Gross Domestic Product in current dollars are from the World Bank's World Development Indicators. Statutory corporate income taxes, representing 
the maximum marginal statutory corporate tax rates in that country in the given year, are from the World Tax Database maintained by the Office of Tax Policy Research at the University of Michigan. Tax rates proxy the attractiveness of the business environment in a country and one would expect that higher tax rates in foreign country would discourage equity flows; additionally Desai, Foley and Hines (2004) find that US companies move equity toward low-tax locations. Distance has been widely used as a proxy for information asymmetry (Portes and Rey, 2005). A variable termed 'relative distance', which is the average distance (in nautical miles) from the capital city of a particular country to Washington, D.C., this distance, is then weighted by GDP of the foreign country. The GDP weights capture the negative relationship between size and information asymmetry. This time-varying proxy for information asymmetry is similar to Alfaro,Kalemli-Ozcan and Volosovych (2006).

Inflation rates, industrial production, and interest rates are taken from the IFS database. Treasury yield or call money yield for are used to measure interest rate series. Interest rate yield spreads are calculated as US interest rate minus host country interest rate. A positive yield spread would indicate that US interest rates are higher than host country interest rates. La Porta, Lopezde-Silanes, Shleifer, and Vishney $(1997,1998)$ emphasize the importance of the historical legal origins in shaping the current financial environment (i.e. attractiveness for portfolio investment). They examine the effect of legal origin on the laws governing investor protection, the enforcement of these laws, and the extent of concentration of firm ownership across countries. Most countries legal rules, either through colonialism, conquest, or outright borrowing, can be traced to four distinct European legal systems: English Common Law, French Civil Law, German Civil Law, and Scandinavian Civil Law. These legal origin variables have been adopted as exogenous determinants of institutional quality, in particular financial markets and institutions (Beck, Demirguc-Kunt and Levine, 2002). To investigate (and control for) whether legal origins have a direct effect on equity inflows by adding legal origin dummies as additional right hand side variables in regressions without fixed effects.

Summary statistics for the transaction flow data, valuation ratios, and country characteristics are given in Table 1.

\section{Table 1: Summary Statistics}

Means, medians, standard deviations, and extreme values for equity flows, stock market valuation ratios and returns are reported in the table below. RLC is the annual country return in local currency from Kenneth French's website, RUSD is the annual country return in USD, M/B is the book to market ratio, $\mathrm{P} / \mathrm{E}$ is the earnings to price ratio, $\mathrm{P} / \mathrm{CE}$ is the cash earnings to price ratio, YLD is the dividend yield. Flow data is from the US Treasury department TIC data, iflow is equity inflow (i.e. from the USA into country i), oflow is equity outflow (i.e. out of country i to USA), and nflow is net equity flow (inflow-outflow). Industrial production, interest rates, and real exchange rates are from IMF International Financial Statistics. Tax rates are from the World Tax Database maintained by the office of Tax Policy Research at the University of Michigan. Distance scaled by GDP is calcu- 
lated using number of nautical miles divided by GDP in current dollars. GDP in current dollars is from World Bank's World Development Indicators. Panel A summarizes equity flow data, Panel B reports valuation ratios and returns and Panel C summarizes country controls and characteristics.

\begin{tabular}{|c|c|c|c|c|c|c|}
\hline & $\mathrm{N}$ & Mean & Median & SD & Min & Max \\
\hline & \multicolumn{6}{|c|}{ Panel A: Equity Flows } \\
\hline Inflow (US to & 494 & 30995.47 & 6107 & 87026.70 & 0 & 676079 \\
\hline & 494 & 32398.73 & 6625.50 & 88954.18 & 0 & 704559 \\
\hline \multirow{2}{*}{$\begin{array}{l}\text { to US) } \\
\text { Net Flow (Inflow- } \\
\text { Outflow) }\end{array}$} & 494 & 1596.74 & 277.50 & 6268.155 & -46134 & 38493 \\
\hline & & & \multicolumn{4}{|c|}{$\begin{array}{l}\text { Panel B: Stock Market valuations and } \\
\text { returns }\end{array}$} \\
\hline $\mathrm{M} / \mathrm{B}$ & 494 & 1.84 & 1.70 & 0.90 & 0.37 & 9.84 \\
\hline $\mathrm{P} / \mathrm{E}$ & 494 & 16.05 & 14.88 & 7.93 & 3.89 & 63.69 \\
\hline $\mathrm{P} / \mathrm{CE}$ & 494 & 8.35 & 7.74 & 4.26 & 1.30 & 38.76 \\
\hline Dividend Yield (\%) & 494 & 3.16 & 2.77 & 1.914 & 0.43 & 14.93 \\
\hline Return (USD) & 494 & 17.13 & 15.83 & 27.27 & -47.33 & 135.8 \\
\hline \multirow{2}{*}{$\begin{array}{l}\text { Return (Local } \\
\text { Currency) }\end{array}$} & 494 & 16.23 & 16.37 & 24.85 & -38.91 & 121.01 \\
\hline & & & \multicolumn{4}{|c|}{$\begin{array}{l}\text { Panel C: Country Characteristics and } \\
\text { controls }\end{array}$} \\
\hline $\begin{array}{l}\text { Industrial } \\
\text { Production }\end{array}$ & 494 & 83.80 & 85.62 & 16.61 & 25.32 & 123.11 \\
\hline $\begin{array}{l}\text { Distance (Scaled by } \\
\text { GDP) }\end{array}$ & 494 & 9.45 & 5.12 & 11.94 & 0.30 & 76.89 \\
\hline $\begin{array}{l}\text { Implied change in } \\
\text { foreign exchange } \\
(\%)\end{array}$ & 494 & 6.68 & 1.00 & 24.40 & -124.00 & 100.00 \\
\hline $\begin{array}{l}\text { Real Foreign } \\
\text { Exchange (1995) }\end{array}$ & 494 & 106.38 & 103.81 & 20.65 & 57.73 & 179.45 \\
\hline $\operatorname{Tax}(\%)$ & 494 & 34.13 & 35.00 & 10.58 & 8.50 & 52.00 \\
\hline CPI (Base=1995) & 494 & 81.21 & 86.84 & 20.38 & 19.92 & 113.34 \\
\hline Interest Rate (\%) & 494 & 6.77 & 5.52 & 4.36 & 0.07 & 19.80 \\
\hline UK Legal Origin & 494 & 0.39 & & & & \\
\hline $\begin{array}{l}\text { French Legal } \\
\text { Origin }\end{array}$ & 494 & 0.42 & & & & \\
\hline $\begin{array}{l}\text { German Legal } \\
\text { Origin }\end{array}$ & 494 & 0.05 & & & & \\
\hline $\begin{array}{l}\text { Scandinavia Legal } \\
\text { Origin }\end{array}$ & 494 & 0.14 & & & & \\
\hline
\end{tabular}

*In regression models, log of CPI, Industrial production, real foreign exchange and distance are used. 
The total number of observations is 494 , some countries lack full data sets (i.e. some early years of equity flow data are unavailable) for Ireland, Malaysia, New Zealand, Belgium, Austria, and Finland. Portfolio equity investment grew rapidly over the period. The mean of net flows for the US in the sample is positive, consistent with the idea that home bias is declining. In this annual data, the net equity flows are small by comparison with gross inflows and outflows. Average equity return for the 21 countries in this study for the sample of 1977-2005 was 17.13 percent in US dollar terms or 16.23 percent in local currency terms. This return compares to the historical market return for Small US firms.

The country with the highest return in given year in my sample period was Italy, with its equity markets up 135 percent in 1985, while the worst return was reported by -47 percent in Hong Kong in 1982. The best average return for the 21 countries in my sample was 1985 with an average return of 56 percent and the worst year for world markets included in my sample was 2001 where markets lost on average of 12.58 percent. The highest median return in was 21.76 percent in Hong Kong, and the lowest median return occurred in Austria at 5.47percent. The average top marginal tax rate for the 21 countries was about 34 percent with the minimum of 8.5 percent occurring in Switzerland for the period of 20012005. The maximum tax rate of 56 percent occurred in Germany from 1977 to 1987. Of the sample about 39 percent was British legal origin, 42 percent were French legal origin, 4.6 percent were Germanic, with the balance of observations being Scandinavian in legal origin.

\section{Results}

A 'stripped' down model is estimated first, to establish the basic correlation between equity flows and stock market valuation ratios. The dependent variable is inflow as a percentage of initial stock and the explanatory variables are the source countries valuation ratios and US valuation ratios. Table 2.2 presents the results of my initial estimations for the entire sample.

Pooled OLS, fixed effects and random effects models are estimated, parameter estimates for all three models are similar and with stable signs. In order to estimate the most efficient model, F-tests for fixed effects are performed and if able to reject the null hypothesis, then Hausman tests for random effects are estimated, under the null hypothesis both the fixed and random effects model are consistent, but the random effects model is more efficient, rejection of the null hypothesis implies that the fixed effects model is most appropriate. Under the null hypothesis, there is no correlation between the repressors and the residuals. The underlying idea of the Hausman test is to compare two sets of estimates, one of which is consistent under both the null and the alternative and another, which is consistent only under the null hypothesis. A large difference between the two sets of estimates is taken as evidence in favor of the alternative hypothesis, or in this case, the fixed effects model. 
Table 2: Equity Flows and Stock Market Valuations (Full Sample): Regressions of equity flows as a percentage of initial position into host country on source and host country market-to-book, price-to-earnings, cash earnings-to-price and dividend yields. White heteroskedastic robust t-statistics are and p-values are reported.

\begin{tabular}{|c|c|c|c|c|c|c|c|c|c|c|c|c|}
\hline Variable & Coef & t-stat & $\mathrm{p}$-value & coef & t-stat & p-value & coef & t-stat & p-value & coef & t-stat & p-value \\
\hline M/B (For) & -2.10 & -3.11 & 0.00 & & & & & & & & & \\
\hline M/B(USA) & 5.97 & 3.92 & 0.00 & & & & & & & & & \\
\hline P/E (For) & & & & -0.22 & -1.71 & 0.09 & & & & & & \\
\hline P/E (USA) & & & & 0.51 & 3.37 & 0.00 & & & & & & \\
\hline P/CE (For) & & & & & & & -0.54 & -11.58 & 0.00 & & & \\
\hline P/CE (USA) & & & & & & & 0.68 & 11.42 & 0.00 & & & \\
\hline Dividend Yield (For) & & & & & & & & & & -0.49 & -3.15 & 0.00 \\
\hline Dividend Yield (USA) & & & & & & & & & & 2.62 & 11.56 & 0.00 \\
\hline Country & & Fixed & & & Fixed & & & Random & & & Fixed & \\
\hline Year & & No & & & No & & & No & & & No & \\
\hline $\mathrm{N}$ & & 494 & & & 494 & & & 494 & & & 494 & \\
\hline R-squared & & 0.16 & & & 0.17 & & & 0.15 & & & 0.14 & \\
\hline
\end{tabular}


Pooled OLS, fixed effects and random effects models are estimated, parameter estimates for all three models are similar and with stable signs. In order to estimate the most efficient model, F-tests for fixed effects are performed and if able to reject the null hypothesis, then Hausman tests for random effects are estimated, under the null hypothesis both the fixed and random effects model are consistent, but the random effects model is more efficient, rejection of the null hypothesis implies that the fixed effects model is most appropriate. Under the null hypothesis, there is no correlation between the repressors and the residuals. The underlying idea of the Hausman test is to compare two sets of estimates, one of which is consistent under both the null and the alternative and another, which is consistent only under the null hypothesis. A large difference between the two sets of estimates is taken as evidence in favor of the alternative hypothesis, or in this case, the fixed effect model.

This procedure is followed for all panel estimates, except when time invariant parameters are included, then pooled OLS are estimated. P-values and t-statistics in all tables are derived using White hereroskedasticity robust standard errors. When the form of heteroskedasticity is not known, it may not be possible to obtain efficient estimates of the parameters using weighted least squares. OLS provides consistent parameter estimates in the presence of heteroskedasticity, but the usual OLS standard errors will be incorrect and should not be used for inference. White (1980) has derived a heteroskedasticity consistent covariance matrix estimator, which provides correct estimates of the coefficient covariance in the presence of heteroskedasticity of unknown form.

Table 2 reports preliminary results of the basic relationships between proxies for equity market valuations and equity flows. The results shed light on the influences of market valuations as long-term empirical determinants of equity flows. The preliminary results indicate that the effect of stock market valuation is two sided. High source country stock market valuations appear to spur outward equity flows and low host country valuation seems to attract inward equity flows, this finding is consistent with Chuhan et al (1998) who also find a negative sign on price-to-earnings ratio for both Asia and Latin America. The results are both statistically and economically significant. A one-unit change in the market to book ratio of the host country leads to a 2 percent decrease in equity flows from the US. The relative wealth effect is substantially stronger for changes in the US with a one-unit increase in market to book ratio leading to an increase in equity flows abroad of 6 percent.

The results of the relationship between price-to-earnings ratio and cashearning-to-price ratios are also negative and all significant at the 10 percent level, they too also appear to be economically significant with an one unit increase in the price-to-earnings ratio leading to a decline in the growth of equity flows of about a quarter of a percent. The results of the relationship between equity flows and valuation are consistent when dividend yield is used to proxy valuation. Increases in dividend yields in the host country leads to a decrease US equity flows. A potential explanation for this relationship, for the case of dividend yield, is that US institutional investors may avoid high dividend paying markets 
in an effort to avoid increased exchange rate risk or hedging activities. However, the positive significant coefficient on US dividend yield further supports the idea that as domestic wealth increases more equity is funneled abroad. If the results on the effects of source country valuation ratios were identified from only cross sectional variation, they would raise concerns. For example, the measured effects of the source valuation ratios might merely reflect the effects of countrylevel differences in accounting conventions (Joos and Lang, 1994, Ball, Kothari, and Robin, 2000). To address such concerns, in unreported results, regressions country-by-country were estimated and then averaged the coefficients to try to isolate the pure time component. The results were very similar. Additionally, the fixed effects estimator will also alleviate these problems (Greene, 2003). The next step of the analysis to attempt to control for other factors of that influences equity flows that may be correlated with valuation ratios in order to reduce omitted variable bias and test the stability of the initial results.

Table 3 presents the results of regressions of market valuation proxies and control variables. The first regression, controls for 'return chasing behavior', widely documented in literature as a short-term determinant of equity flows. Bohn and Tesar (1996) coined the phrase 'return chasing', it is generally proxied in empirical work as a positive relationship between lagged returns and equity flows. The second variable controlled for in the first model of table 3 is the log of distance scaled by GDP following Alfaro et al (2005). ${ }^{1}$ The previous results showing that valuation ratios are important determinants of long-term equity flows remain significant both statistically and economically. The coefficient estimates are not significantly altered and the signs remain consistent.

Similar to Portes and Rey (2005), no evidence of returns chasing is uncovered in the full data set. This could be in large part due to the nature of my empirical methodology, while the use of annual data is common for the determination of long-run factors that influence capital flows, to capture the dynamic relationship between variables as suggested by Bohn and Tesar (1996) more frequent observations are required. Distance, which was recently used by Portes et al (2005) to proxy information asymmetries, is found to be negative and statistically significant. This result is consistent with a large literature, which hypothesizes that information asymmetries lead to exaggeration of the home bias puzzle. The interpretation for the negative coefficient on my time varying measure of distance is logical. As the distance between nations shrinks or the size of the economy grows, information asymmetries decline and more equity flows to these countries. Several additional models are estimated including more variables that have been found to be significant in literature to see how the results are were influenced. When more controls are included, the positive coefficient on the valuation ratio for the US becomes insignificant. This indicates that my initial strong results for source country valuation ratios are suspect. However, the negative relationship between valuation of foreign markets and equity flows remains robust, using either price-to-earnings or market-to-book. 
Table 3: Equity Flows and Stock Market Valuations (Full Sample): Regressions of equity flows as a percentage of initial position into host country on source and host countries market-to-book, price-to-earnings and controls. White heteroskedastic robust t-statistics are and p-values are reported.

\begin{tabular}{|c|c|c|c|c|c|c|c|c|c|c|c|c|}
\hline Variable & coef & t-stat & $\mathrm{p}$-value & coef & t-stat & p-value & coef & t-stat & p-value & coef & t-stat & p-value \\
\hline MB (For) & -2.04 & -9.64 & 0.00 & -2.05 & -10.51 & 0.00 & & & & -1.89 & -8.38 & 0.00 \\
\hline MB (USA) & 3.44 & 4.68 & 0.00 & 0.75 & 1.01 & 0.31 & & & & 2.90 & 4.09 & 0.00 \\
\hline $\mathrm{P} / \mathrm{E}$ (For) & & & & & & & -0.18 & -6.49 & 0.00 & & & \\
\hline P/E (USA) & & & & & & & -0.08 & -1.02 & 0.31 & & & \\
\hline \multicolumn{13}{|l|}{ P/CE (For) } \\
\hline \multicolumn{13}{|l|}{ P/CE (USA) } \\
\hline \multicolumn{13}{|l|}{ Dividend Yield (For) } \\
\hline \multicolumn{13}{|l|}{ Dividend Yield (USA) } \\
\hline Return (t-1) & 0.00 & -0.82 & 0.41 & & & & & & & & & \\
\hline Industrial Production (log) & & & & 4.68 & 5.23 & 0.00 & 5.72 & 5.95 & 0.00 & 4.27 & 3.71 & 0.00 \\
\hline Distance (log) & -2.10 & -4.00 & 0.00 & -1.07 & -1.57 & 0.11 & -1.06 & -1.83 & 0.07 & -1.36 & -2.47 & 0.01 \\
\hline \multicolumn{13}{|l|}{ CPI $(\log )$} \\
\hline \multicolumn{13}{|l|}{ Implied Change in Forex } \\
\hline Interest Rate & & & & -0.36 & -6.01 & 0.00 & -0.44 & -6.75 & 0.00 & -0.23 & -4.09 & 0.00 \\
\hline Tax Rate & & & & -0.06 & -2.13 & 0.03 & -0.05 & -1.77 & 0.08 & -0.08 & -4.11 & 0.00 \\
\hline UK Legal Origin & & & & & & & & & & 0.64 & 1.30 & 0.19 \\
\hline French Legal Origin & & & & & & & & & & -0.76 & -1.49 & 0.14 \\
\hline German Legal Origin & & & & & & & & & & -0.59 & -0.69 & 0.49 \\
\hline Country & & Fixed & & & Fixed & & & Fixed & & & Pooled OLS & \\
\hline Year & & No & & & No & & & No & & & No & \\
\hline $\mathrm{N}$ & & 494 & & & 494 & & & 494 & & & 494 & \\
\hline $\mathrm{R}$-squared & & 0.20 & & & 0.25 & & & 0.23 & & & 0.19 & \\
\hline
\end{tabular}

Country fixed effects are included if the f-test for fixed effects rejects the null and the Hausman test for random effects also rejects the null.

Pooled OLS is estimated when time-invariant repressors are included. 
Additional controls are also added to capture the relative productivity of the economy, interest rate spreads, and tax rates. Table 3 reports that when the spread between US interest rates and foreign interest rates increase, investors tends to decrease flows as a percentage of initial positions from the US to host nations. This is consistent with the finding of Calo, Leiderman and Reinhart (1993) who document that reduction in interest rate spread in Argentina lead to a sharp increase in capital flows. One explanation for this phenomenon is that increases in foreign interest rates will lead to depreciation of currency and therefore subject the US investors to increased interest rate risk. Alternatively, the fact that flows are negatively related to interest rate spreads can be explained, as simply US investors tend to stay at home when interest rates are relatively high. A third explanation is that high US interest rates may have decreased Americans wealth, and therefore decreased their risk tolerance, causing them to rebalance away from foreign equities.

Table 3 also reports a significant negative coefficient on tax rates. This is consistent with the findings of Densi et al (2002) that capital flows to environments with lower tax rates, and is also consistent with the findings that increases in taxes reduces expected returns. A panel regression that includes dummy variables for legal origin was also estimated. Several papers have found that legal origin proxies institutional structure and investiblity (Beck et al, 2002). However, in the full sample no statistically significant relationship is present. The signs on the legal origin variables are, however, consistent with other literature that finds that British origin indicates strong institutional structure, whereas French and German legal origin have a negative effect on flows.

To summarize, the association between country level stock valuations and equity flows in mostly developed countries are studied. A strong new fact about equity flows is documented: there is a very strong negative link between host country stock market valuations and equity flows. Indeed, the effect of host country valuations is almost as strong, in statistical terms, as any other determinants of equity flows included in this study. This paper is the first, to my knowledge, to document the role of valuation in developed markets as a determinant of equity flows and indicates that large US portfolio allocation decisions are negatively related to high valuations in host countries.

\section{Conclusions}

The majority of theories of equity flows assume that the world capital markets are informationally efficient and integrated. However, various lines of empirical evidence suggest that country-level shocks to investor optimism or risk aversion, combined with information asymmetry, sometimes cause the same capital asset to sell for different prices in different locations. These observations suggest that valuation may be an important determinant of cross-border equity flows.

This research discusses and empirically evaluates the effects of US and host country valuation as a determinant of equity flows from the US to mainly developed nations. To provide a large-sample test, country and year variation 
in stock market valuations, realized returns, and country controls are exploited. The results are consistent with the view that equity flows increase from the US to abroad when US valuations are high, indicating a sort of 'wealth effect' of equity flows. Additionally, host country valuations are strongly and consistently negatively related to flows. This indicates that US portfolio investors seek 'undervalued' equity markets and increase flows to these markets as valuations decline. Several findings consistent with literature are also documented, the negative role of information asymmetries on equity flows, the positive influence of productivity on equity flows, the fact that as US interest rates are high the American investors stay at home, and the negative influence of taxes on equity investment abroad. In conclusion, while the results of this research certainly do not find that other explanations of the determinants of equity flows are unimportant, they do appear to indicate that equity market valuations are an important piece of the puzzle in understanding the behavior of cross-border equity flows.

Author statement: Corresponding author is Joseph French, Monfort College of Business, Box 128, Greely, CO 80639.Tel:970.351.1226.Email: joseph.french@ unco.edu. This paper was reviewed by one of the editors, and by anonymous reviewer before being edited to conform to the format of the Journal. The author wishes to thank the editorial office, and the reviewer while acknowledging responsibility for remaining errors.

\section{References}

Alfaro, L., Kalemli-Ozcan, S., and Volosovych, V., (2005). Capital Flows in a Globalized World: The Role of Policies and Institutions, NBER Working Papers 11696, National Bureau of Economic Research, Inc.

Baker, Malcolm, P., Foley, C., Fritz, and Wurgler, Jeffrey, A., (2007). Multinationals as Arbitrageurs? The Effect of Valuations on Foreign Direct Investment, Working Paper. Formerly NBER Working Paper Series, No.10449, forthcoming in the Review of Financial Studies

Basu, Saniov, (1983). The relationship between earnings' yield, market value and return for NYSE common stocks: Further evidence, Journal of Financial Economics 12: 129-56.

Beck, T., Demirguc-Kunt, and A. Levine., R., (2002), Law and Finance: Why does Legal Origin Matter, Worldbank working paper.

Bohn, H., and Tesar, L., (1996). US equity investment in foreign markets: Portfolio rebalancing or return chasing? American Economic Review 86 (2): 77-81.

Brunnermeier, Markus, and Stefan Nagel, (2004). Hedge funds and the technology bubble, Journal of Finance 59: 2013-2040

Calvo, G., A., Leiderman, L., and Reinhart, C.,M., (1993). Capital inflows and real exchange rate appreciation in Latin America: The role of external factors, IMF Staff Papers, Washington, DC. 
Chuhan, P., S. Claessen, and N. Mamigni, (1998). Equity and bond flows to Latin America and Asia: the role of global and country factors, Journal of Development Economics 55: 439-463

Desai, Mihir, C. Fritz Foley, and James R. Hines Jr., (2004). Foreign Direct Investment in would of multiple taxes, Journal of Public Economics 88: 2727-2744.

Fama, Eugene F., and Kenneth R. French, (1992), The cross-section of expected stock returns, Journal of Finance 47, 427-465.

Fama, Eugene F., and Kenneth R. French, (1998). Value versus growth: The international evidence, Journal of Finance 53: 1975-1999.

Froot, Kenneth A., and Emil M. Dabora, (1999), How are stock prices affected by the location of trade? Journal of Financial Economics 53: 189-216.

Greene, W., (2003), Econometric Analysis, Prentice Hall, 5th edition

Griffin J., F. Nardari, and R. Stulz, (2004), Daily Cross-Border Equity Flows: Pushed or Pulled?, The Review of Economics and Statistics, 2004, vol. 86 (issue 3): 641-657.

Hau, H., and H. Rey, (2006): Exchange Rate, Equity Prices and Capital Flows, Review of Financial Studies, 2006, vol. 19 (issue 1): 273-317

Hausman, A., Jerry, and Taylor E. William, (1980). Panel Data and Unobserved Individual Effects, Economtrica, 49: 66-87.

Kothari, S.P., and Jay Shanken, (1997). Book-to-market, dividend yield, and expected market returns: A time-series analysis, Journal of Financial Economics 44: 169-203.

La Porta, Rafael, Josef Lakonishok, Andrei Shleifer, and Robert Vishny, (1997). Good news for value stocks: Further evidence on market efficiency, Journal of Finance 52: 859-874.

Pontiff, J., and L.D. Schall, (1998). Book-to-market ratios as predictors of market returns, Journal of Financial Economics 49: 141-160

Portes R., and H. Rey, (2005). The Determinants of Cross-Border Equity Flows, Journal of International Economics, 65: 269-296.

Shleifer, Andrei, (2000). Inefficient Markets: An Introduction to Behavioral Finance, Oxford University Press, Oxford.

Stulz, R, (1999). Globalization of Equity Markets and the Cost of Capital, NBER Working Papers 7021.

Tesar, L., and I., Werner, (1994). International equity transactions and U.S. portfolio choice. In: Frankel, J. (Ed.), The Internationalization of Equity Markets, University of Chicago Press, Chicago, IL, pp. 185-215.

The US Offshore Funds Directory, (1999), New York. 